\title{
Sinopsis de los fundamentos: Libro IV de la Suma sobre el reconocimiento del señor ${ }^{1}$
}

\author{
Utpaladeva \\ Presentación y traducción del sánscrito por Óscar Figueroa \\ Universidad Nacional Autónoma de MÉXico \\ Contacto: figueroa@crim.unam.mx
}

\section{Presentación}

Utpaladeva fue un excepcional filósofo y poeta oriundo de Cachemira, región que entre los siglos VIII y XI se convirtió en una de las grandes capitales de la cultura clásica de la India. Ahí, al pie del Himalaya, florecieron la poética y la dramaturgia sánscritas; alcanzaron un desarrollo sin paralelos la gramática, la lógica y la filosofía del lenguaje; y en el ámbito religioso, la región auspició una asombrosa diversidad y ductilidad. Nacido en los primeros años del siglo x, Utpaladeva se formó en el entrecruce de todas estas tradiciones y su rica obra da cuenta de ello. Destaca, en particular, su habilidad para recoger el imaginario de la plétora de cultos heterodoxos, entonces en boga, y transformarlo en un discurso sofisticado, capaz de dialogar con otras escuelas, incluso el budismo, con base en criterios de verdad canónicos. Utpaladeva estuvo en condiciones de lograr esto no sólo por sus dotes intelectuales, sino además por haber sido él mismo un iniciado en dichos cultos.

Centrados en el dios Shiva y en diversas deidades femeninas concebidas como las potencias del dios, las energías (śakti) que presiden sobre la realidad física y mental, estos cultos reciben el nombre genérico de "tantra" o tradición tántrica. Los primeros exponentes de un teísmo tántrico fueron ascetas de los alrededores de la sociedad brahmánica, quienes encontraron un mecanismo de afirmación y emancipación en la exploración ritual de lo que la opinión común consideraba como impuro (Sanderson, 1985; Torella, 2015). Al frecuentar crematorios y portar calaveras, al ingerir sustancias prohibidas y resignificar ritualmente el deseo, dichos

${ }^{1}$ Este trabajo fue posible gracias al Programa de Apoyos para la Superación del Personal Académico (PASPA) de la UNAM, a través de una estancia sabática a lo largo de 2019 en la École française d'Extrême Orient (EFEO), en Puducherry, India. 
grupos buscaron exhibir la fragilidad del modelo jerárquico brahmánico, para el cual el bien supremo necesariamente debe situarse más allá de la actividad mental y volitiva, más allá de la temporalidad y la finitud (Figueroa, 2017: 33-62). Entre los siglos VIII y IX, esta crítica y los ideales que le son implícitos se desplegaron entre los círculos de iniciados in actu, sin un discurso elaborado y, por consiguiente, al margen del debate filosófico riguroso. Esto cambió precisamente con Utpaladeva, quien, además de haber sido un brahmán formado en la tradición escolástica sánscrita, era, como dije, un iniciado tántrico.

La confluencia de estas dos facetas alcanzó su madurez conceptual en la doctrina del "reconocimiento" (pratyabhijñ $\bar{a}$ ), nombre también de la escuela con la que se identifica a nuestro autor, y que es el núcleo teórico de lo que hoy se conoce popularmente como Shivaísmo de Cachemira. Los orígenes de esta escuela se remontan al siglo IX, en especial en la figura de Somānanda, quien fue elogiado por el propio Utpaladeva (véase aquí mismo IV.16). El esfuerzo pionero de Somānanda por recoger la visión transgresora tántrica en una teología monista que postula la presencia de un mismo principio en todo cuanto existe, más allá de las diferencias puro-impuro, superior-inferior, interior-exterior, etcétera, alcanzó, sin embargo, su esplendor en la magnum opus de nuestro autor: la Suma sobre el reconocimiento del Señor (İsvara-pratyabhijñā-kārikāa), de la que aquí se ofrece la traducción del cuarto libro.

En dicha obra, Utpaladeva enseña que todas las cosas, todo lo que nos rodea y también la vida mental y afectiva, son la manifestación de una única conciencia (citi) autónoma y omnipotente, identificada a su vez con la pareja divina, Shiva y su potencia o Shakti. En términos filosóficos, esto significa que por su propia voluntad (svätantrya), la conciencia despliega dentro de sí misma, como imágenes en un lienzo, todo cuanto existe. Caracterizada como un principio luminoso (prakāśa), la conciencia es siempre ella más sus contenidos, su propio reflejo (vimarśa). En términos soteriológicos, puesto que todo es conciencia y nada hay en realidad que ate o condene al sujeto, a fin de liberarse éste debe disipar sus dudas y abrazar en su propio ser (ätman) el reconocimiento (pratyabhijñāa) de que siempre ha sido, es y será Shiva.

El cuarto y último libro de la Suma constituye el umbral idóneo para acercarse al pensamiento de Utpaladeva, pues se trata, como establece su título, de una "sinopsis" o "síntesis" (sańgraha) de los "fundamentos" o "principios" (tattva) de la doctrina del reconocimiento. Así, Utpaladeva deja atrás los densos argumentos y las complejas digresiones de los tres primeros libros, y en unas cuantas líneas expone la esencia de su planteamiento: por su sola voluntad, la subjetividad divina, que es una y absoluta, se contrae en la subjetividad individual limitada, proceso del que 
se deriva la realidad objetiva diferenciada y contrapuesta al sujeto. Para recuperar su verdadera identidad, el individuo debe revertir este proceso de contracción de vuelta a la unidad expansiva de la conciencia divina.

Esta traducción, la primera directa del sánscrito al español, comprende tanto las breves "sentencias" (kārikā) que conforman el cuarto libro de la Suma como el comentario en prosa escrito por el propio Utpaladeva y titulado simplemente Glosa (Vrtți). Cabe decir que Utpaladeva escribió un segundo autocomentario sobre la Suma, el extenso y complejo Vivrti, que por desgracia nos ha llegado de manera fragmentaria y cuya edición sigue pendiente. Mi traducción tanto de la Suma como de la Glosa se basa en el texto editado por Raffaele Torella.

Por último, sobra decir que esta publicación forma parte del esfuerzo por hacer más visible en español la riqueza del pensamiento filosófico de la India.

Óscar Figueroa

\section{Suma sobre el reconocimiento del Señor Libro IV: Sinopsis de los fundamentos}

1. El verdadero y único ser de todas las creaturas es Maheshvara, ${ }^{2}$ el Señor supremo, quien colma el universo entero, plenamente consciente de la unidad de sujeto y objeto.

El Señor supremo colma el universo entero, él es el único ser [de todas las creaturas], es decir, [el ser] que comparten todos los seres vivos, pues desde la perspectiva del estado último, que no es sino la meta primera, él rebosa de la experiencia prodigiosa del sujeto indiferenciado, el objeto indiferenciado y la unión de ambos.

2. Al respecto, el Señor supremo, el verdadero sujeto de conocimiento, hace que cosas como el intelecto, etcétera, creadas por él como objetos para sí mismo, sean conceptualizadas como aspectos de la subjetividad [limitada].

Cuando este [universo] emana del Señor supremo como su propia expansión, cosas como el intelecto, el alma o la vacuidad, que [él] percibe precisamente como objetos, a pesar de no ser sino un aspecto más de la realidad objetiva, una vez que

\footnotetext{
${ }^{2}$ Maheshvara, literalmente "gran Señor" o "Señor supremo", es otro nombre del dios Shiva.
} 
son conceptualizadas como componentes de la subjetividad, acaban constituyendo al sujeto limitado.

3. Y cuando se desconoce la verdadera naturaleza de cada uno de esos sujetos individuales, se acaba asumiendo su pluralidad. De este modo, la actividad y la beatitud [divinas] se reducen a la experiencia [respectivamente] de dolor y placer.

El acto de delimitar aquello que posee una naturaleza universal es precisamente lo que se denomina falta de reconocimiento (pratyabhijña $\bar{a}$. Del mismo modo, el entendimiento que reduce el sujeto supremo a una pluralidad de sujetos compuestos por un intelecto, un alma, etcétera, es a lo que se llama falta de conocimiento supremo. En esta pluralidad de individuos que se presentan como sujetos, el Señor supremo, en tanto único y verdadero sujeto, delimita sus propias obras y su propia dicha. Se llama a esta experiencia "placer" porque consiste en una pequeña porción de la dicha [divina] y "dolor" porque es una partícula de la acción [divina]. La relación entre acción y dolor se explicará más adelante.

4. La sabiduría, la actividad y, en tercer lugar, la forma aparente que todos los seres obtienen del Señor, pues éstos son una extensión suya, corresponden en el sujeto limitado a [los atributos de] la ecuanimidad (sattva), el ímpetu (rajas) y el letargo (tamas). ${ }^{3}$

En efecto, la sabiduría, la acción y la ilusión divinas cobran la forma, en el sujeto limitado, de ecuanimidad, ímpetu y letargo.

5. Si bien de estos atributos se derivan causas y efectos, no alcanzan el estatus de potencias (śakti) del Señor debido al estado de diferenciación [en el que cobran sentido].

Puesto que la ecuanimidad, el ímpetu y el letargo se manifiestan de manera independiente, es incorrecto llamarles potencias, pues una potencia no es distinta de quien la posee. La verdad es, por supuesto, que todo cuanto existe es una manifestación de la potencia [divina].

6. El Señor posee la existencia, la beatitud y la acción; el sujeto esclavizado posee eso, su ausencia y ambas cosas juntas, es decir, [la ecuanimidad, el letargo y] el ímpetu o dolor, que no es sino la mezcla de los otros dos [atributos].

El Señor posee una capacidad infinita para obrar, un asombroso poder para actuar cuyos rasgos distintivos son la luz y la beatitud absolutas. En el sujeto individual esta luz y esta beatitud se transforman, sin embargo, en entidades limitadas para constituir lo que se denomina "ecuanimidad" (sattva). Su ausencia es lo que

\footnotetext{
${ }^{3}$ Es decir, los tres grandes "atributos” o "cualidades" (guna) del orden finito, tanto en el plano físico como en el mental, de acuerdo con la escuela dualista Sān̉khya (véase İ́svarakṛ̣ṇa [1979: 11-13]), aquí retomada por Utpaladeva desde una perspectiva teísta y monista.
} 
se llama "letargo" (tamas). Aunque ecuanimidad y letargo son dos cosas distintas — por un lado, luz y beatitud; por el otro, su ausencia—, su combinación produce lo que se conoce como "ímpetu" (rajas). En el sujeto limitado, la acción, [la cual está asociada con] el dolor, lleva por nombre "ímpetu".

7. Incluso las cosas que el Señor percibe en su conciencia como realidades objetivas no convencionales, se manifiestan de diversas maneras ya sea por sí mismas o combinadas entre sí.

Todas esas cosas que para el Señor guardan el sentido de un objeto, incluso si carecen del referente lingüístico "esto", pues, como le ocurre a los niños, basta su luminosidad para aprehenderlas, una vez creadas por el propio Señor, se presentan como entidades particulares — pues su sustrato común se pluraliza- y con diferentes apariencias — pues su aspecto común se diversifica-.

8. En cambio, [en el caso del sujeto limitado], las cosas que se manifiestan por separado y con aspectos diversos, quedan fijadas en su memoria, imaginación, etcétera, con muchos nombres diversos.

Debido a este poder de fijación [mental], las cosas que se manifiestan por separado como entidades universales son representadas como objetos dentro de la conciencia con diferentes nombres, por ejemplo, "jarrón”, "plata”, "vestido blanco", "carreta", etcétera, y condicionado por esta experiencia, el sujeto se vuelve él mismo objeto de toda clase de representaciones, tales como "soy delgado", "soy feliz", "soy infeliz", etcétera. [Esto sucede] en la memoria a través del recuerdo de experiencias previas; en la imaginación desbordada, en cambio, de manera autónoma. Esta manifestación de la diferencia entre sujeto y objeto, articulada lingüísticamente, es lo que para el sujeto limitado constituye el yugo del samsara. ${ }^{4}$

9-10. Su creación es particular y depende de la creación del Señor, existe gracias a la potencia divina, pero incapaz de reconocer esto a pesar de ser idéntico al Señor, dicha potencia circula en la forma del hálito vital, deviene actividad mental y se diversifica en la multitud de fonemas, impidiéndole reposar en su verdadera naturaleza.

A pesar de ser idéntico al Señor, el sujeto individual es incapaz de reconocer la potencia divina, y debido a ello construye [internamente] diferentes entidades universales que, si bien son imperceptibles para los demás, están moldeadas por la experiencia de objetos que son comunes a todos. Llamada ahora "ilusión" (māyā), la potencia divina contiene la suma completa de todos los fonemas (el fonema "K",

${ }^{4}$ De acuerdo con prácticamente todas las filosofías de la India, el samsara (saṃsāra) es el ciclo repetido de nacimiento y muerte que experimenta el individuo mientras vive presa de la ignorancia. Es el orden finito. 
etcétera), se desplaza sin cesar a través de la respiración y opera como actividad mental, creando así internamente los objetos e impidiendo que el sujeto repose en su verdadera naturaleza.

11. La creación del Señor es, en cambio, muy distinta, sea ésta común o no a todos, pues se manifiesta con absoluta transparencia. El plano del Seńor se alcanza gradualmente por medio de un enfoque concentrado que elimina los constructos mentales.

Por su parte, la creación del Señor [es muy distinta], tanto cuando es común a todos los sujetos, por estar conjuntamente inmersos en ella, como cuando concierne a un sujeto y se reduce sólo a él, por ejemplo en el sueńo, en el error, etcétera. Y se dice que se manifiesta con absoluta transparencia porque, al consistir únicamente en la conciencia de identidad del sujeto con el objeto, no hay diferencias y, por lo tanto, no se producen constructos mentales. A este respecto, al entregarse por completo a disolver la incesante actividad de la mente y sus constructos, quienes viven en el samsara poco a poco, a medida que se impone la condición del Señor, es decir, la experiencia de unidad, consiguen trascender su condición como sujetos limitados.

12. Quien ve su ser en todas las cosas y finalmente comprende: "Yo soy el autor de este prodigio", incluso en medio de la actividad mental, alcanza el estado del Señor supremo.

Aun en el estado en el que, gracias a la potencia del Señor, persiste la actividad mental, el sujeto individual que reconoce su naturaleza divina y se funde con todas las cosas sin distinción, pensando "Yo soy el autor del prodigio que es el samsara", transforma todos sus constructos en reflejos de la conciencia divina y, así, alcanza él también el estado del Señor supremo.

13. Al igual que el Señor supremo, quien se ha liberado [del yugo del samsara] considera la realidad común y a la vista de todos como indistinta de sí mismo. En cambio, [el sujeto limitado] la considera por completo distinta de sí mismo.

El individuo esclavizado y el liberado perciben una misma realidad. Sin embargo, el primero la percibe como algo por completo distinto [a él], mientras que el segundo como su propio cuerpo.

14. Y cuando absorbe plenamente dentro de sí la suma completa de todos los componentes de la realidad, es Shiva mismo, una masa de conciencia y dicha, y su cuerpo la sílaba primordial.

Ahora bien, si absorbe por completo en su interior la realidad cognoscible y se identifica plenamente con el Yo [divino], él alcanza el estado de Shiva.

15. De este modo, al experimentar directamente su verdadera naturaleza, así como sus [verdaderas] facultades de acción y conocimiento, percibe y crea objetos según su designio. 
Tras reconocer al Señor como su propio ser, rebosante de infinitos poderes para conocer y actuar, manifiestas todas las señales de dichos poderes, él percibe y crea todas las cosas según su voluntad.

\section{[Epílogo]}

16. Es así como, con base en lo expuesto por el gran maestro [Somānanda] en su tratado La visión de Shiva (Śivadrșți), ${ }^{5}$ he explicado este nuevo y sencillo camino. Cualquiera que ponga un pie en él, despliegue en su propio ser la esencia del creador del universo, es decir, la esencia de Shiva, y se absorba para siempre [en esta experiencia], alcanza la meta.

En la vida cotidiana con todas sus vicisitudes, el estado de Shiva sólo puede alcanzarse por medio de este acto de reconocimiento. Tras experimentar directamente al Señor supremo en todo su esplendor, el venerable maestro Somānanda expuso [por primera vez] este novedoso y sencillo sendero en su libro titulado $\mathrm{La}$ visión de Shiva. Por mi parte, a fin de ahondar en dicho sendero, he ofrecido aquí una demostración lógica. Cualquiera que se consagre a su estudio hasta hacerse uno con Shiva, alcanza la liberación en esta misma vida.

17. Tal como una hermosa doncella que, tras múltiples avances y súplicas, recibe a su pretendiente, así lo tenga delante suyo, mientras no lo reconozca, creerá que es cualquier hombre y no experimentará dicha; del mismo modo, mientras una persona no descubra las cualidades del Señor universal, que no es sino su propio ser, es simplemente imposible que conozca su verdadera grandeza. Es por ello que aquí se ha expuesto en qué consiste el reconocimiento del Señor.

El ejemplo del pretendiente prueba por qué es necesario reconocer al Señor y cuán extraordinario es el fruto.

18. Con el fin de que la gente pueda alcanzar la perfección sin ningún esfuerzo, Utpaladeva, hijo de Udayakāra, ha explicado en qué consiste el reconocimiento del Señor.

Se ha mostrado así este sencillo camino a la perfección.

${ }^{5}$ Como mencioné en la presentación, a Somānanda, autor de finales del siglo Ix y principios del siglo $\mathrm{x}$ también oriundo de Cachemira, se atribuye la primera formulación de la doctrina del reconocimiento. Ésta aparece articulada en su obra principal, La visión de Shiva (Śivadrșți), de la que hay traducción al inglés (Somānanda, 2011). 


\section{[Colofón:]}

Titulado "Sinopsis de los fundamentos", aquí concluye el cuarto y último capítulo de la Suma sobre el reconocimiento del Señor, junto con su respectiva Glosa, ambas escritas por Utpaladeva.

\section{Referencias bibliográficas}

Figueroa, Óscar. (2017). El Vijñāna Bhairava Tantra. Barcelona: Kairós. İ́́vARAKRṢ̦Na. (I979). Sānkhyyakārikā (G. Larosn, ed.). Delhi: Motilal Banarsidass. SANDERson, Alexis. (1985). "Purity and power among the Brahmans of Kashmir". En S. Collins et al. (eds.), The category of the person: anthropology, philosophy, history. Cambridge: Cambridge University Press. 190-216.

SomĀnanda. (2011). Sivadrsțti (J. Nemec, ed.). Oxford: Oxford University Press. Torella, Raffaele. (2015). "Purity and impurity in nondualistic Śaiva Tantrism". Studia Religiologica, 48(2), 101-115. https://doi.org/10.4467/20844077 SR.15.008.3554.

Utpaladeva. (2002). Ísvarapratyabhijn̄äkärikā (con el comentario Vrtti) (R. Torella, ed.). Delhi: Motilal Banarsidass. 